\title{
The Caloric Contribution of Protein-Containing Foods
}

\author{
Wendy Van Ausdal ${ }^{1, *}$, Stacey J. Bell ${ }^{2}$ and Greg Grochoski ${ }^{3}$
}

${ }^{1}$ IdeaSphere Inc, 600 E. Quality Drive, American Fork, UT 84003, USA; ${ }^{2}$ Nutritional Consultant, Former IdeaSphere Inc Employee, 56 Amherst Rd. Belmont, MA 02478; ${ }^{3}$ IdeaSphere Inc, 3133 Orchard Vista Drive, SE, Grand Rapids, MI 49546

\begin{abstract}
Vegetarians consume more nutrient-dense diets, have lower body mass indexes (BMIs), and most have less chronic disease than non-vegetarians. The diet seems appealing but it is important to consider the caloric contribution of vegetarian proteins. We assigned $28 \mathrm{~g}$ of protein as the ideal intake for a single meal. Next we determined the corresponding number of calories for 33 commonly consumed vegetarian and non-vegetarian protein-containing foods. Usually $28 \mathrm{~g}$ protein from vegetarian sources had more calories than non-vegetarian ones. The average caloric contribution was $267 \pm 47$ calories $/ 28 \mathrm{~g}$ protein from meats and $737 \pm 141$ calories $/ 28 \mathrm{~g}$ protein from seeds and nuts. Assuming that vegetarians consume adequate protein, they need to reduce energy intake from other foods, have increased energy expenditures, or both, to avoid weight gain. South Asians consume mainly a vegetarian diet but have a high incidence of heart disease. More work is needed to determine if the optimal diet is, indeed, vegetarian.
\end{abstract}

\section{INTRODUCTION}

A vegetarian diet contains no animal products. Subcategories of this diet include: lacto-vegetarians (those who abstain from eating eggs and all meat, but consume milk and milk products), lacto-ovo-vegetarians (those who do not eat any meat, but who do eat eggs and dairy products), and vegans (those who do not eat any meat or animal-derived ingredients) [1]. Most vegetarian protein sources are healthier than non-vegetarian proteins, because they have less total fat, saturated fat, and cholesterol and more fiber than equivalent protein from animal sources [2-4]. The United States Continuing Survey of Food Intake by Individuals 1994-1996, 1998 reported that $2.3 \%$ of the population is vegetarian [2]. However, from that group, less than one percent avoided meat, fish or poultry based on 24-hour dietary recall data, indicating that most only occasionally follow a strict vegetarian diet [2].

Most individuals who consume vegetarian diets weigh less, have lower body mass index (BMI; in $\mathrm{kg} / \mathrm{m}^{2}$ ) values, and are healthier than those who don't [4-6]. For the most part, they have a lower incidence of obesity, cardiovascular disease (CVD), and type 2 diabetes [5, 7]. However, in South Asia, following a vegetarian diet is not always associated with a reduced risk of CVD [8-10].

With all these health benefits associated with a vegetarian diet, it was surprising to learn that most vegetarian protein-containing foods have more energy per gram than nonvegetarian ones. The purpose of this review article is to present the energy contribution of equivalent amounts of protein from vegetarian and non-vegetarian foods. This information serves to educate healthcare professionals, patients, and the lay public regarding one downside of a vegetarian diet.

*Address correspondence to this author at the IdeaSphere Inc, $600 \mathrm{E}$. Quality Drive, American Fork, UT 84003, USA; Tel: 801 492-7398;

Fax: 801 763-0789; E-mail: wvanausdal@isibrands.com
In order to avoid weight gain in those who consume vegetarian proteins, other measures must be employed (e.g., decrease energy consumption from non-protein-containing foods, increase energy expenditure, etc.).

\section{MATERIALS AND METHODOLOGY}

We compared the energy contribution of 33 commonly consumed proteins from vegetarian and non-vegetarian foods containing equal amounts of protein. A priori, we set $28 \mathrm{~g}$ of protein to be the typical amount consumed at one meal. This was based on the Recommended Dietary Allowance (RDA) of $56 \mathrm{~g}$ for men and $46 \mathrm{~g}$ for women, so that the 28 -g portion represented about one-half of the daily protein need [11].

The energy and protein content of these proteincontaining foods was determined from the United States Department of Agriculture (USDA) Nutrient Data Laboratory [12]. Each protein-containing food assessed herein was considered to be of equal biological value. In the past, mixing poorer quality complementary proteins (e.g., rice and beans) was thought to be necessary to provide the right mixture of amino acids to support protein synthesis [13]. However, newer research indicates that all essential amino acid needs can be adequately met by eating an assortment of plant-based protein-containing foods over the course of a day [7].

\section{RESULTS AND DISCUSSION}

Vegetarian and non-vegetarians foods, each containing $28 \mathrm{~g}$ of protein, are presented in Table $\mathbf{1}$.

Vegetarian protein-containing foods, for the most part, have substantially more calories than the equivalent amount of protein from non-vegetarian sources. On average, for the same amount of protein $(28 \mathrm{~g})$, meats and dairy had the fewest calories of the foods assessed. Meats and dairy had 35\% and $7 \%$ fewer calories than legumes, $64 \%$ and $49 \%$ fewer calories than seeds and nuts, and 69\% and 56\% fewer calories than grains, respectively. 
Table 1. Protein and Energy Content of Selected Foods

\begin{tabular}{|c|c|c|}
\hline Food & $\begin{array}{l}\text { Amount Needed to } \\
\text { Provide } 28 \text { g Protein }\end{array}$ & Calories \\
\hline \multicolumn{3}{|l|}{ Meat (cooked) } \\
\hline Beef & 3.3 oz. $(93.6 \mathrm{~g})$ & 193 \\
\hline Fish & 4.5 oz. $(127.6 \mathrm{~g})$ & 263 \\
\hline Veal & 3.7 oz. $(104.9 \mathrm{~g})$ & 279 \\
\hline Chicken & 4 oz. $(113.4 \mathrm{~g})$ & 279 \\
\hline Lamb & $4 \mathrm{oz} .(113.4 \mathrm{~g})$ & 321 \\
\hline Average & & $267 \pm 47$ \\
\hline \multicolumn{3}{|l|}{ Dairy } \\
\hline Cottage Cheese (1\%) & 1 cup (226 g) & 163 \\
\hline Milk (fat free or skim) & 3.3 cups $(815 \mathrm{~g})$ & 285 \\
\hline Soy Milk $(2 \%)$ & 2.6 cups $(632 \mathrm{~g})$ & 331 \\
\hline Milk (2\%) & 3.5 cups $(854 \mathrm{~g})$ & 427 \\
\hline Cheddar Cheese & 0.9 cups $(119 \mathrm{~g})$ & 452 \\
\hline Yogurt (fruit blend, nonfat) & 2.6 cups $(637 \mathrm{~g})$ & 599 \\
\hline Average & & $376 \pm 151$ \\
\hline \multicolumn{3}{|l|}{ Legumes } \\
\hline Soybeans & 1 cup (172 g) & 298 \\
\hline Lentils & 1.5 cups $(297 \mathrm{~g})$ & 345 \\
\hline Split Peas & 1.7 cups $(333 \mathrm{~g})$ & 393 \\
\hline Kidney Beans & 1.8 cups $(319 \mathrm{~g})$ & 405 \\
\hline Black Beans & 1.8 cups $(310 \mathrm{~g})$ & 409 \\
\hline Navy Beans & 1.9 cups $(346 \mathrm{~g})$ & 484 \\
\hline Garbanzo Beans & 1.9 cups (312) & 511 \\
\hline Average & & $406 \pm 74$ \\
\hline \multicolumn{3}{|l|}{ Grains } \\
\hline Whole Wheat Flour & 1.7 cups (204 g) & 692 \\
\hline Triticale Flour & 1.6 cups $(208 \mathrm{~g})$ & 703 \\
\hline Buckwheat Flour & 1.8 cups $(216 \mathrm{~g})$ & 724 \\
\hline Quinoa & 3.4 cups $(629 \mathrm{~g})$ & 764 \\
\hline Couscous & 4.7 cups $(738 \mathrm{~g})$ & 826 \\
\hline Barley Flour & 1.8 cups $(266 \mathrm{~g})$ & 919 \\
\hline Millet & 4.6 cups $(800 \mathrm{~g})$ & 952 \\
\hline Brown Rice & 6 cups $(1170 \mathrm{~g})$ & 1310 \\
\hline Average & & $861 \pm 206$ \\
\hline \multicolumn{3}{|l|}{ Seeds and Nuts } \\
\hline Pumpkin Seeds & 0.8 cups $(110 \mathrm{~g})$ & 597 \\
\hline Peanut Butter & 0.4 cups $(103 \mathrm{~g})$ & 607 \\
\hline Black Walnuts & 0.9 cups $(113 \mathrm{~g})$ & 695 \\
\hline Sunflower Seeds & 0.9 cups $(126 \mathrm{~g})$ & 739 \\
\hline Almonds & 0.9 cups $(129 \mathrm{~g})$ & 744 \\
\hline Pistachios & 1.1 cups $(135 \mathrm{~g})$ & 754 \\
\hline Cashews & 1.3 cups $(178 \mathrm{~g})$ & 1022 \\
\hline Average & & $737 \pm 141$ \\
\hline
\end{tabular}

Consumption of 3.3 to 4.5 ounces of chicken, beef, veal, fish or lamb yielded $28 \mathrm{~g}$ of dietary protein, and had an average caloric contribution of $267 \pm 47$ (range 193-321). For dairy products, 0.9 to 3.5 cups provided $28 \mathrm{~g}$ of protein, and had an average caloric value of $376 \pm 151$ (range 163-599). One to 1.9 cups of legumes provided $28 \mathrm{~g}$ of protein, and contained an average of $406 \pm 74$ calories (range 298-511). Eating 0.8 to 1.3 cups of seeds and nuts, or almost a half a cup of peanut butter, provided $28 \mathrm{~g}$ of protein, and had an average caloric value of $737 \pm 141$ (range 597-1022). For grains, in order to get $28 \mathrm{~g}$ of protein, 1.6 to 6 cups needed to be consumed, which contained an average of $861 \pm 206$ calories (range 692-1310).

\section{Excess Energy Intake from Vegetarian Proteins}

A typical vegetarian meal providing $28 \mathrm{~g}$ of protein could include one and a half cups of lentils, containing 345 calories. The same amount of protein from a non-vegetarian source (e.g., 4-ounce piece of cooked chicken) has only 279 calories. Thus, the vegetarian protein food provided 66 more calories $(23.7 \%)$ than the non-vegetarian food, which may not be big enough difference to induce weight gain. On the other hand, a 28 -gram protein serving of almonds ( 0.9 cups) contains 744 calories, or 465 more calories (167\%) than an equivalent amount of protein from chicken. Regular consumption of protein from seeds and nuts would likely induce weight gain over time if other strategies are not adopted.

If we assume that substituting one vegetarian protein food for a non-vegetarian food once a week for one year, and that $3,500 \mathrm{kcal}$ equaled $0.45 \mathrm{~kg}$ of body weight, then the theoretical weight gain would be:

- $0.44 \mathrm{~kg}$ for eating lentils at one meal/week [66 calories X 52 weeks $=3432$ calories; $3432 \times(0.45 \mathrm{~kg} / 3500 \mathrm{kcal})]$.

- $3.1 \mathrm{~kg}$ for eating almonds at one meal/week [465 calories X 52 weeks $=24,180$ calories; 24,180 X $(0.45 \mathrm{~kg} / 3500$ kcal)].

\section{Energy Intake/Energy Expenditure}

It is logical to assume that vegetarians would weigh more than non-vegetarians due to the differences in energy per gram of protein, but this is not the case [2, 4, 5, 14]. Vegetarians have adopted other healthy dietary (consume less energy from non-protein-containing foods) and healthrelated (increase energy expenditure) habits to avoid weight gain [2-5].

In terms of dietary intake, vegetarians consume more nutrient-dense foods and avoid those rich in fat compared to non-vegetarians [4]. They consumed more grains (yeast breads and rolls, cereals and pasta, and rice) (354 $\pm 18 \mathrm{~g}$ vs. $303 \pm 2 \mathrm{~g})$ than non-vegetarians each day, a difference of $14 \%$. Similarly, vegetarians daily consumed more vegetables $(250 \pm 14$ g vs. $197 \pm 1 \mathrm{~g})$ and fruits $(261 \pm 18 \mathrm{~g}$ vs. $159 \pm 2$ g) than non-vegetarians, or $21 \%$ and $39 \%$ less per day, respectively [2]. The diet of vegetarians and vegans is significantly richer in fiber $(\mathrm{P}<0.001)$ than non-vegetarians $(29.4 \pm$ $2.1 \mathrm{~g}$ vs. $19.9 \pm 0.4 \mathrm{~g}$ for males and $20.9 \pm 1.1 \mathrm{~g}$ vs. $15.5 \pm$ $0.3 \mathrm{~g}$ for females) $[3,4]$. Grains, fruits, and vegetables are low-fat, nutrient-dense, and fiber-rich. Thus, unlike nutrientpoor, high-fat foods, these foods promote satiety and may help control hunger and cravings. These dietary differences may explain the lack of weight gain in vegetarians, despite eating more calorically-dense protein sources.

In terms of energy expenditure, vegetarians are more likely to engage in physical activity than non-vegetarians [4, 
5]. More vegetarians than non-vegetarians (36.8\% versus $17.3 \%$, respectively; $\mathrm{P}<0.001)$ engaged in more than four hours per week of intense exercise. Such practices aid in maintaining a healthy weight, and can potentially off-set the extra calories coming from vegetarian proteins.

\section{Weight and Vegetarian Diets}

Vegetarians have lower body weights and BMIs than those consuming a non-vegetarian diet [4-6]. Female vegetarians weighed about $5.4 \mathrm{~kg}$ less and males about $5.9 \mathrm{~kg}$ less, than non-vegetarian, gender-matched subjects [4-6]. The mean BMI $\left(\mathrm{kg} / \mathrm{m}^{2}\right)$ of vegetarians is between one and three $\mathrm{kg} / \mathrm{m}^{2}$ units less than that of non-vegetarians $[4,5,14$, 15]. Thus, a vegetarian diet appears to be satisfying enough to maintain a healthy weight loss.

A vegetarian diet can even foster weight loss [16]. Those who followed a vegan diet lost weight faster and kept it off better than those who followed a heart-healthy, low-fat diet [16]. Overweight women were randomly assigned to either one of these diets for 14 weeks and then followed for two years. Those in the vegan group lost significantly more weight than those on the heart-healthy diet at both year one $(-4.9 \mathrm{~kg}$ vs. $-1.8 \mathrm{~kg} ; \mathrm{p}<0.05)$ and year two $(-3.1 \mathrm{~kg}$ vs. -0.8 $\mathrm{kg} ; \mathrm{p}<0.05)$. In the future, strategies for weight loss and maintenance should include some aspects of a vegan or vegetarian diet.

\section{Disease Risk}

The vegetarian diet appears to reduce health risks in Europeans and North Americans [5, 7]. First, most vegetarian proteins are healthier than non-vegetarian proteins, because they contain less total fat, saturated fat, and cholesterol, and more fiber than equivalent protein from animal sources [2, 3, 4]. Second, a vegetarian diet is healthier - it contains more cereals, fiber, fruits and vegetables, and less cholesterol - than one consumed by non-vegetarians [2-4].

As a result, vegetarians have lower risks for chronic diseases of aging like CVD, type 2 diabetes, cancer, and obesity, and take fewer prescription drugs than non-vegetarians $[5,7]$. Compared to non-vegetarians, lacto-ovo-vegetarians and vegans had mean blood cholesterol levels that were $14 \%$ and $35 \%$ lower, respectively, than non-vegetarians [7]. Vegetarians have both lower systolic and diastolic blood pressures (about 5 to $10 \mathrm{~mm} / \mathrm{Hg}$ ) than non-vegetarians [7]. Thirteen percent of vegetarians have hypertension compared to $42 \%$ of non-vegetarians. The death rate from ischemic heart disease is $31 \%$ lower in vegetarian men and $20 \%$ lower in vegetarian women than in their non-vegetarian counterparts. Among men, the risk for diabetes is $80 \%$ higher in non-vegetarians than vegetarians. Non-vegetarians had a $54 \%$ increased risk for prostate cancer and an $88 \%$ increased risk for colon cancer than non-vegetarians [7].

Inhabitants of South Asia (Pakistan, India, Bangladesh, Nepal, and Sri Lanka) do not seem to reap the same benefits of a vegetarian diet on risk reduction, especially for CVD, as do Westerners [5, 7-10, 17]. Most South Asian populations consume a vegetarian diet, or at least one that includes very little meat, eggs, and fish [9]. Their diet is also rich in total fat, which comes from trans fatty acids (vegetable ghee), clarified butter (Indian ghee), other visible fats, and dairy products [10]. The high-fat intake, which could be up to $50 \%$ of total energy intake, had more of an effect on exacerbating risk factors of CVD in those who lived in urban environments than in rural settings $[9,10]$. The prevalence of CVD was three times higher in the urban population compared to a rural one. However, those consuming the more visible fats, regardless of where they lived, had the highest risk.

Total fat intake and energy intake are lower in South Asia than Western societies, but CVD prevalence is still high $(\sim 30 \%)$ [8]. Other factors (socioeconomic status, cultural mores, and religious issues) become drivers of CVD risk in South Asia [9, 17]. For example, the highest three of five socioeconomic classes had a greater intake of proatherogenic foods, had higher BMIs, and were more sedentary than those in the lower two classes [9]. Each of these factors may contribute to the higher prevalence of CVD in higher socioeconomic classes. One-third of the South Asian population is obese and half are classified as being overweight [17]. As this region gains more wealth, the incidence of obesity is expected to rise. Some have argued that the most important measures to prevent CVD are to eat a low-fat diet and engage in physical activity. Neither of these measures are usually followed in urban settings, but are in rural ones [8].

For South Asians, simply following a low-fat, vegetarian diet and exercise program will not prevent all CVD [8, 17]. These individuals develop type 2 diabetes at lower BMIs than Westerners. In addition, low-density-lipoprotein cholesterol concentrations may be slightly elevated or near normal, unlike those living in Western societies. Instead, South Asians have elevated serum triglycerides and low highdensity-lipoprotein cholesterol concentrations, putting them at greater risk for insulin resistance and metabolic syndrome. Thus, a South Asian paradox exists in that simply following a vegetarian diet does not seem to be enough to reduce chronic disease risk. There are too few Westerners who follow the diet of South Asians, but it is possible with more information that this same paradox may become elucidated.

\section{CONCLUSION}

Vegetarian protein-containing foods have more calories than equivalent amounts of protein from non-vegetarian foods. Despite this, vegetarians have lower BMIs than nonvegetarians and, for the most part, are healthier than nonvegetarians. Vegetarians from Western countries have reduced risks of CVD, type 2 diabetes, and obesity. Those living in South Asian, who mostly consume a lacto-ovovegetarian diet, still have a $30 \%$ prevalence of CVD. A paradox exists as to why this is so high, but it may be attributed to moving to an urban setting and engaging in less physical activity. In order to avoid obesity and chronic disease risk, those following a vegetarian diet in either a Western culture or in South Asia need to reduce energy consumption from non-protein-containing foods and adopt other healthier lifestyles (e.g., increase physical activity).

\section{CONFLICT OF INTEREST}

All authors have contributed to this work and agree to submit it for consideration to The Open Nutraceuticals Journal. All of the authors are current or past full-time employees of IdeaSphere Inc., a manufacturer and purveyor of die- 
tary supplements. IdeaSphere Inc., does not sell vegetarian food products.

\section{REFERENCES}

[1] Mayo Clinic Staff. Vegetarian diet: How to get the best nutrition [article on the internet]. Mayo Foundation for Medical Education and Research; 2008 [cited 2008 Jan 7]. Available from: http:// www.mayoclinic.com/print/vegetarian-diet/HQ01596/METHOD= print.

[2] Haddad EH, Tanzman JS. What do vegetarians in the United States eat? Am J Clin Nutr 2003; 78: 626S-32S.

[3] Janelle KC, Barr SI. Nutrient intakes and eating behavior scores of vegetarian and nonvegetarian women. J Am Diet Assoc 1995; 95: $180-6$.

[4] Bedford JL, Barr SI. Diets and selected lifestyle practices of selfdefined adult vegetarians from a population-based sample suggest they are more 'health conscious'. Int J Behav Nutr Phys Act 2005; 2: 4 .

[5] Alewaeters K, Clarys P, Hebbelinck M, Deriemaeker P, Clarys JP. Cross-sectional analysis of BMI and some lifestyle variables in Flemish vegetarians compared with non-vegetarians. Ergonomics 2005; 48: 1433-44.

[6] Key T, Davey G. Prevalence of obesity is low in people who do not eat meat. BMJ 1996; 313: 816-7.

[7] American Dietetic Association; Dieticians of Canada. Position of the American Dietetic Association and Dieticians of Canada: Vegetarian diets. J Am Diet Assoc 2003; 103: 748-65.

[8] Nishtar S. Prevention of coronary heart disease in south Asia. Lancet 2002; 360: 1015-8.

[9] Singh RB, Beegom F, Verma SP, et al. Association of dietary factors and other coronary risk factors with social class in women in five Indian cities. Asia Pac J Clin Nutr 2000; 9: 298-302.
[10] Singh RB, Niaz MA, Ghosh S, et al. Association of trans fatty acids (vegetable ghee), and clarified butter (Indian ghee) intake with higher risk of coronary artery disease, in rural and urban populations with low fat consumption: The Indian Paradox. Int J Cardiol 1996; 56: 289-98.

[11] Panel on Macronutrients, Subcommittees on Upper Reference Levels of Nutrients and Interpretation and Uses of Dietary Reference Intakes, and the Standing Committee on the Scientific Evaluation of Dietary Reference Intakes (U.S.). Dietary Reference Intakes for Energy, Carbohydrate, Fiber, Fat, Fatty Acids, Cholesterol, Protein, and Amino Acids (Macronutrients) [book on the internet]. Washington: National Academy Press; 2005 [cited 2007 Aug 1]. Available from: http://www.nap.edu/catalog.php?record_id=10490\#toc

[12] USDA Nutrient Data Laboratory [homepage on the internet]. [cited 2007 Aug 1]. Available from: http://www.nal.usda.gov/fnic/foodcomp/search/.

[13] Jacobs C, Dwyer JT. Vegetarian children: appropriate and inappropriate diets. Am J Clin Nutr 1988; 48: 811-8.

[14] Haddad EH, Berk LS, Kettering JD, Hubbard RW, Peters WR. Dietary intake and biochemical, hematologic, and immune status of vegans compared with nonvegetarians. Am J Clin Nutr 1999; 70: 586S-93S.

[15] Spencer EA, Appleby PN, Davey GK, Key TJ. Diet and body mass index in 38,000 EPIC-Oxford meat-eaters, fish-eaters, vegetarians and vegans. Int J Obes 2006; 27: 728-34.

[16] Turner-McGrievy CM, Barnard ND, Scialli AR. A two-year randomized weight loss trial comparing a vegan diet to a more moderate low-fat diet. Obesity $2007 ; 15: 2276-81$.

[17] Pella D, Thomas N, Tomlinson B, Singh RB. Prevention of coronary artery disease: the south Asian paradox. Lancet 2003; 361: 79.

(c) Ausdal et al.; Licensee Bentham Open.

This is an open access article licensed under the terms of the Creative Commons Attribution Non-Commercial License (http://creativecommons.org/licenses/by$\mathrm{nc} / 3.0 /$ ) which permits unrestricted, non-commercial use, distribution and reproduction in any medium, provided the work is properly cited. 